\title{
РОЗВИТОК ТЕОРІЇ ФІНАНСОВОГО ЛЕВЕРИДЖУ ТА ВИМІРЮВАННЯ ЙОГО БАНКІВСЬКИХ ЕФЕКТІВ У ФІНАНСУВАННІ ІННОВАЦІЙНОӤ КОНКУРЕНТОСПРОМОЖНОСТІ ПІДПРИЕМСТВ
}

У статті адаптовано традиційний підхід до вимірювання ефекту фінансового левериджу в реальному секторі економіки до специфіки банківської діяльності иляхом визначення методичних підходів до розрахунку середньозваженої вартості залученого і позикового капіталів, які на додаток до коефіцієнте структури капітал, містять податковий коректор $і$ диференціал фінансового левериджу, який доповнено моделлю максимізації формування власного капіталу банку при дотриманні встановлених лімітів формування резервів на знецінення активів банківської установи й узгодження різних за термінами активів $і$ пасивів, забезпеченні прибутковості здійснюваних банком операцій $і$ виконання нормативів капіталу. Вимірювання ефектів фінансового левериджу із застосуванням даного підходу дозволить на практиці обтрунтовувати рішення щуодо формування фінансового забезпечення інноваційної конкурентоспроможності підприємств, оцінювати їх економічну доцільність в умовах обмеженого доступу до ринків капіталу.

Використання розроблених пропозицій та рекомендацій щуодо вдосконалення формування банківського капіталу сприятиме підвищенню його ефективності, зниженню рівня ризиків, забезпечуватиме достатність банківського капіталу і матиме позитивний вплив на зростання вартості банківського бізнесу та капіталізації банківської системи, ї̈ стабільність й економічне зростання начіональної економіки.

Ключові слова: банк, капітал, структура капіталу, фінансовий леверидж, банківський прибуток

\section{Вступ}

Розмір i структура капіталу банківських установ визначають їх успішний розвиток на мікрорівні, а на макрорівні становлять об'єктивну основу ефективності функціонування банківської системи загалом. При цьому розмір банку, його спеціалізація, інші екзогенні й ендогенні чинники накладають свій відбиток на вибір джерел фінансування активних операцій i політику формування банківського капіталу. У сучасних умовах функціонування грошово-кредитного ринку актуальною $\epsilon$ проблема формування такої структури капіталу банківських установ, яка б забезпечувала достатню ї капіталізацію. Як інститут особливого типу, банк, виступаючи фінансовим посередником по контрактах, характеризується особливостями вибору джерел формування капіталу, що зумовлює утворення певної його структури. Остання, у свою чергу, може служити імпульсом або до зростання вартості банку, або до його знецінення та банкрутства.

Запорукою стійкого розвитку банку в умовах мінливого середовища $\epsilon$ ефективна система корпоративного управління, що має відповідати провідним світовим практикам. Ïї невід'ємною складовою виступає формування банківського капіталу з позицій взаємоузгодження інтересів акціонерів, клієнтів, кредиторів банку тощо.

\section{Аналіз останніх досліджень i публікацій \\ Суттєвий внесок у дослідження} питань, пов'язаних із формуванням капіталу банківських установ, зробили зарубіжні вчені і вітчизняні вчені: Р. Гропп [1], О. Ікпефан [2], М. Октавія [3], Д. Хенкок [4], М. Алексеєнко [5], Н. Версаль [6], А. Вожжов [7], Ж. Довгань [8], С. Реверчук [9] та ін. Разом 3 цим існуючі розробки та рекомендації неповною мірою враховують особливості формування капіталу у специфічних умовах функціонування вітчизняної банківської системи та не містять дієвих стимулів до збільшення іiі капіталізації. Потребують вирішення питання розвитку теорії фінансового левериджу та вимірювання його ефектів у банківській сфері.

\section{Мета статті}

Розробка теоретичних положень, методичних основ i практичних рекомендацій щодо виміру ефектів фінансового левериджу із врахування специфіки банківської діяльності.

\section{Методи дослідження}

Для формалізації ефекту фінансового левериджу банківської установи використано методи економікоматематичного моделювання, для визначення достатньої капіталізації банків і обгрунтування змін в оподаткуванні банківського прибутку - методи оптимізації. 


\section{Виклад основного матеріалу}

Фінансовий леверидж характеризує використання банком залучених і позикових коштів, що впливає на зміну рентабельності власного банківського капіталу. Показник, що відображає рівень додаткового прибутку на власний капітал банку, що генерується, за різної частки використання залученого i позикового капіталу, називається ефектом фінансового левериджу. Такий показник розроблявся переважно для суб'єктів господарювання реального сектору економіки, які мають обмежену кількість кредитів і джерел позикових коштів взагалі, на відміну від банків, у розпорядженні яких знаходяться значні обсяги залучених i позикових коштів, різних за видами. Тому, грунтуючись на поняттях «процентна маржа», «чиста процентна маржа», «чистий спред» [10, с. 2677-2703], пропонуємо модифікувати загальновідому формулу коефіцієнту фінансового левериджу таким чином:

$$
\begin{aligned}
& D F L=(1-t) \cdot\left(R O A-r_{w}\right) \cdot \frac{D}{E}= \\
& =(1-t) \cdot\left(R O A-\frac{\mathrm{IE}+\mathrm{CSL}}{F C A+A L}\right) \cdot \frac{D}{E}
\end{aligned}
$$

де $t$ - ставка податку на прибуток, частки од.;

$R O A$ - рентабельність активів, частки од.; $r_{w}$ - середньозважена вартість залученого і позикового капіталів, частки од.;

$D$ - залучений і позиковий капітал, тис. грн;

$E$ - власний капітал, тис. грн;

$I E$ - процентні витрати, тис. грн;

$C S L$ - витрати на обслуговування кредитів, тис. грн;

$F C A$ - підпроцентні депозити, тис. грн;

$A L$ - залучені кредити, тис. грн.

Слід відмітити, що рівень фінансового важеля зростає зі збільшенням частки залучених i позикових коштів у банківському капіталі. 3 одного боку, чим більше залученого і позикового капіталів та відсотки за ними, тим дієвішим $\epsilon$ фінансовий важіль, тим більше можливостей для активізації фінансової діяльності, а 3 іншого боку, відбувається збільшення ризику втрати фінансової стійкості. Одним iз напрямів застосування формули (1) $€$ обгрунтування і оцінка ефективності рішень щодо формування банківського капіталу.

Розглянемо на умовному прикладі визначення цільової структури банківського капіталу 3 урахуванням пруденційних обмежень й оцінку прийнятих рішень на основі ефекту фінансового левериджу. Вихідна інформація для розрахунків представлена у табл. 1.

Таблиця 1

\begin{tabular}{|c|c|c|}
\hline $\begin{array}{c}\text { Фактична структура капіталу } \\
(Y) \text { - частка власного капіталу } \\
\text { у загальному капіталі банку }\end{array}$ & $\begin{array}{c}\text { Цільова структура } \\
\text { капіталу }\left(Y^{*}\right)\end{array}$ & $\begin{array}{c}\text { Коефіцієнт відповідності } \\
\text { фактичної структури } \\
\text { капіталу цільовій (Квияк) }\end{array}$ \\
\hline 0,1250 & 0,1459 & \multirow{3}{*}{0,8568} \\
\hline $\begin{array}{l}\text { у т. ч. в абсолютному виразі, } \\
\text { тис. грн }\end{array}$ & $\begin{array}{l}\text { У т. ч. в абсолютному виразі, } \\
\text { тис. грн }\end{array}$ & \\
\hline 2888201 & 3371108 & \\
\hline
\end{tabular}

Окремі показники формування капіталу банку

3 табл. 1 видно, що для побудови цільової структури капіталу, банківській установі необхідно підвищити частку власного капіталу 3 12,50\% до $14,59 \%$ (3371108 тис. грн). Як один 3 варіантів стратегії формування банківського капіталу можна обрати стратегію збільшення власного капіталу шляхом тезаврації (реінвестування) прибутку. Разом 3 цим набуває важливості визначення того, як ці зміни вплинуть на діяльність банку, його надійність. 3 цією метою побудуємо модель максимізації приросту власного капіталу 3 урахуванням дотримання встановлених резервів на знецінення активів банківської установи. Більш детально дана економіко- 
математична оптимізаційна модель представлена у роботі [11]

Цільова функція максимізації приросту власного капіталу за рахунок нерозподіленого прибутку $Z$ (2) враховує дотримання

$$
Z=\frac{\left(\begin{array}{l}
\sum_{i=1}^{S I} x_{i} \frac{r_{i} \cdot n_{i}}{\left(1-q_{i}\right) \cdot n}+\sum_{i=S I+1}^{C I} x_{i} \cdot\left(\left(1+r_{i}\right)^{n_{i}} \cdot\left(1-q_{i}\right)^{-\frac{1}{n}}-1\right)+\sum_{i=S I+C I+1}^{S D} x_{i}\left(\frac{d_{i}}{1-n_{i} d_{i}-q_{i}}\right)+(1-T) \\
+\sum_{i=S D+1}^{c D} x_{i} \cdot\left(\left(1-n \cdot d-q_{i}\right)^{-\frac{1}{n_{i}}}-1\right)+I^{\Sigma}{ }_{t}-E^{\Sigma}{ }_{t}-\sum_{i=1}^{n} g_{i} \cdot x_{i}
\end{array}\right.}{\sqrt{\sum_{j=1}^{J}\left(1-\frac{\sum_{i=1}^{i_{j}} x_{i}}{s_{j}}\right)^{2}}} \rightarrow \max
$$

формування резервів на знецінення активів банківської установи й узгодження різних за термінами активів і пасивів. де $\mathrm{x}_{\mathrm{i}}$ - обсяг банківського капіталу, що направляється на здійснення і-го виду активних операцій, тис. грн;

$\mathrm{r}_{\mathrm{i}}\left(\mathrm{d}_{\mathrm{i}}\right)$ - ставка відсотка за i-м видом активів (облікова ставка відсотка), частки од.

$\mathrm{n}_{\mathrm{i}}$ - термін функціонування активу і-го виду, років;

$\mathrm{g}_{\mathrm{i}}$ - ставка резервування за i-м видом активів, частки од.;

SI (SD), CI (CD) - кількість активів, за якими нараховуються прості та складні відсотки, од.;

$I^{\Sigma}{ }_{t}-$ загальний обсяг процентних доходів від активних операцій, здійснених раніше, та інших видів доходу в наступному періоді, тис. грн;

$E^{\Sigma}{ }_{t}-$ сукупний обсяг процентних та інших видів витрат у наступному періоді, тис. грн; $q_{i}-$ комісійні, що утримуються банком, частки од.;

$\mathrm{s}_{\mathrm{j}}$ - обсяг зобов'язань терміном $\mathrm{j}$, які передбачається погасити за рахунок коштів, що надійдуть від повернення активів, вкладення в які банк планує здійснити, тис. грн;

$T$ - ставка податку на прибуток банку, частки од.
Обмеженнями цільової функції (2) є: забезпечення беззбитковості діяльності банку, здійснення активних операцій банківською установою в межах залишків коштів на коррахунку в НБУ, попит з боку позичальників й емітентів, дотримання достатнього рівня регулятивного капіталу, неперевищення розміру резервів за активними операціями відповідних лімітів.Залучені банком кошти протягом місяця 3 початку року склали 881313 тис. грн, у тому числі: строкові депозити 616919 тис. грн, депозити до запитання 264394 тис. грн (3 них резервна база 15781,7 тис. грн (норматив обов'язкового резервування за строковими депозитами $3 \%$, за коштами на поточних рахунках та депозитами на вимогу $-6,5 \%$ ).

У табл. 2 наведені значення даних окремих параметрів оптимізаційної моделі, які використовуються для проведення розрахунків.

За допомогою «Пошуку рішення» Excel було знайдено розв'язок задачі нелінійного програмування, якою $\epsilon$ оптимізаційна модель. 
Таблиця 2

Прогнозні дані попиту на кредитування

(за інформацією банківської установи і з урахуванням інтересів банку) у розрізі термінів надання, відсотки за кредитами

\begin{tabular}{|c|c|c|c|c|c|}
\hline Вид активу & 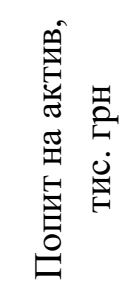 & 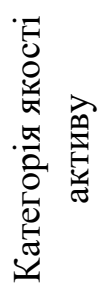 & 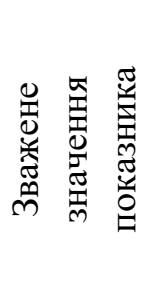 & 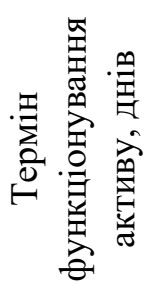 & 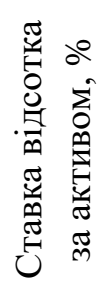 \\
\hline А. Кредитування фізичних осіб & 79000 & I & 0,03 & 60 & 22 \\
\hline Б. Кредитування фізичних осіб & 83000 & I & 0,06 & 120 & 24 \\
\hline В. Кредитування фізичних осіб & 181000 & II & 0,16 & 30 & 28 \\
\hline Г. Кредитування юридичної осіб & 340000 & $\mathrm{I}$ & 0,02 & 60 & 15,7 \\
\hline Д. Кредитування юридичної осіб & 248500 & I & 0,04 & 180 & 25 \\
\hline Ж. Кредитування юридичної осіб & 1560 & I & 0,06 & 300 & 20 \\
\hline 3. Кредитування юридичної осіб & 9500 & II & 0,13 & 420 & 14,6 \\
\hline К. Кредитування юридичної осіб & 17500 & II & 0,16 & 180 & 23 \\
\hline Л. Кредитування бюджетних установ & 370000 & $\mathrm{I}$ & 0,06 & 300 & 21 \\
\hline
\end{tabular}

Таблиця 3

Обсяг процентних доходів від здійснених вкладень в активи та процентних витрат, очікуваних інших доходів і витрат банку у розрахунковому періоді

\begin{tabular}{|l|c|}
\hline \multicolumn{1}{|c|}{ Показник } & Обсяг, тис. грн \\
\hline Процентні доходи від раніше здійснених вкладень в активи & 144529 \\
\hline Процентні витрати & 98853 \\
\hline Інші доходи (очікувані) & 48920 \\
\hline Інші витрати (очікувані) & 30120 \\
\hline
\end{tabular}

Таблиця 4

Обсяг сформованих резервів для відшкодування можливих втрат за раніше здійсненими активними операціями, обсяг регулятивного капіталу банку і зважених за ризиком активів

\begin{tabular}{|l|c|}
\hline \multicolumn{1}{|c|}{ Показник } & Обсяг, тис. грн \\
\hline $\begin{array}{l}\text { Сформовані резерви для відшкодування можливих } \\
\text { втрат за активними операціями }\end{array}$ & 3926194 \\
\hline Регулятивний капітал & 2623221 \\
\hline Активи, зважені на ризик & 21607546 \\
\hline Сукупні активи & 23105607 \\
\hline
\end{tabular}


Обсяги залучених зобов'язань банком у розрізі термінів

\begin{tabular}{|c|c|}
\hline $\begin{array}{c}\text { Терміни залучення } \\
\text { зобов'язань, днів }\end{array}$ & Обсяг зобов'язань, тис. грн \\
\hline від 30 до 60 & 164034 \\
\hline від 61 до 90 & 100360 \\
\hline від 91 до 120 & 0 \\
\hline від 121 до 150 & 21,3 \\
\hline від 151 до 180 & 100000 \\
\hline від 181 до 210 & 0 \\
\hline від 211 до 240 & 0 \\
\hline від 241 до 270 & 121116 \\
\hline від 271 до 300 & 0 \\
\hline від 301 до 330 & 100000 \\
\hline від 331 до 360 & 0 \\
\hline від 361 до 390 & 0 \\
\hline від 391 до 420 & 280000 \\
\hline
\end{tabular}

Розв'язок задачі максимізації приросту власного капіталу 3 урахуванням дотримання встановлених резервів на знецінення активів банку матиме наступний вигляд:

цільова функція $\Delta \mathrm{K}$ складе 168188,247 вектор оптимальних значень змінних $\mathrm{X}=(79000 ; 83000 ; 0 ; 32502,647 ; 248500$; $1560 ; 9500 ; 0 ; 370000)$ - рис. 1.

Для порівняння розрахунків зведемо їх у табл. 6. тис. грн,

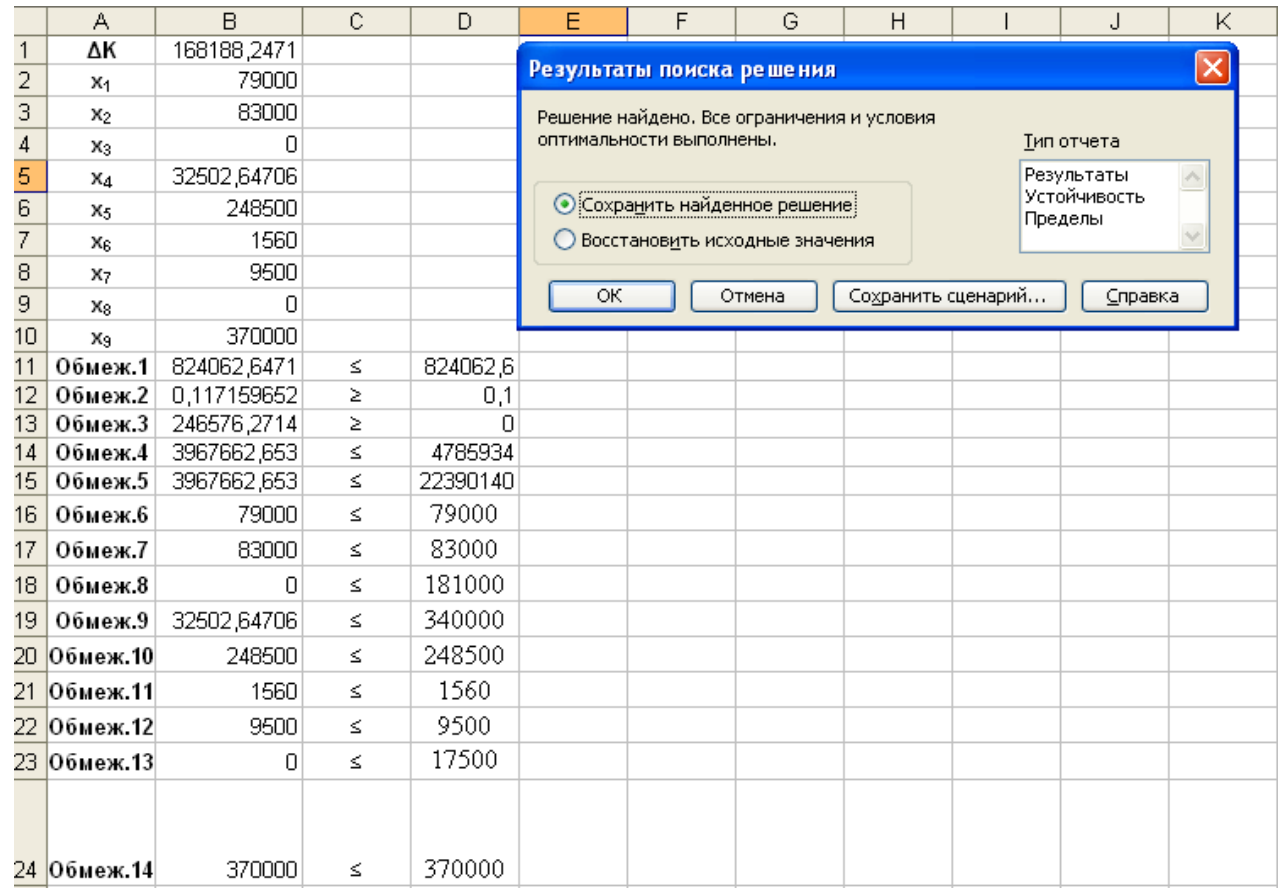

Рис. 1 Розв'язок задачі максимізації приросту власного капіталу

3 урахуванням дотримання встановлених резервів на знецінення активів банківської установи (фрагмент робочого листа Excel) 
Порівняння результатів розрахунків за оптимізаційною моделлю

\begin{tabular}{|l|c|c|c|}
\hline \multicolumn{1}{|c|}{ Вид активу } & $\begin{array}{c}\text { Попит на } \\
\text { актив, тис. } \\
\text { грн }\end{array}$ & $\begin{array}{c}\text { При цільовій } \\
\text { функції } \Delta K\end{array}$ & $\begin{array}{c}\text { Відхилення } \\
+/-, \text { тис. грн }\end{array}$ \\
\hline А. Кредитування фізичних осіб & 79000 & 79000 & 0 \\
\hline Б. Кредитування фізичних осіб & 83000 & 83000 & 0 \\
\hline В. Кредитування фізичних осіб & 181000 & 0 & -181000 \\
\hline Г. Кредитування юридичної осіб & 340000 & 32502,647 & $-307497,353$ \\
\hline Д. Кредитування юридичної осіб & 248500 & 248500 & 0 \\
\hline Ж. Кредитування юридичної осіб & 1560 & 1560 & 0 \\
\hline 3. Кредитування юридичної осіб & 9500 & 9500 & 0 \\
\hline К. Кредитування юридичної осіб & 17500 & 0 & -17500 \\
\hline Л. Кредитування бюджетних установ & 370000 & 370000 & 0 \\
\hline \multicolumn{1}{|c|}{$\Delta К$} & & 168188,247 & \\
\hline
\end{tabular}

Здійснимо оцінку змін у структурі капіталу за допомогою формули (1).

$D F L_{1}=(1-0,18) \cdot((0,005170+0,000262)$

- $(0,004905+0,00016)) \cdot 6,97=0,0021$ або $0,21 \%$.

Отже, зміни у структурі банківського капіталу у наближенні до цільової його структури привели до зростання ефекту фінансового важеля на 0,06 в. П. $(\triangle D F L=0,21-0,15=0,06 \quad$ в. п.) за рахунок зростання $R O A$ на 0,0003 в. п. у місячному обчисленні та збільшенні плеча фінансового левериджу з 6,89 до 6,97 - табл. 7.

Таким чином запропоновані рекомендації щодо вимірювання ефектів фінансового левериджу в банківській сфері дозволять обгрунтовувати рішення щодо формування капіталу з позиції ефективності, забезпечувати формування банківського капіталу близького до цільового.

\section{Обговорення результатів}

Використання

пропозицій дозволило сформувати структуру капіталу банку, наближену до цільової, збільшивши рівень його капіталізації, i забезпечити дотримання пруденційних вимог щодо капіталу відповідно до стандартів Базель III. Ефективне використання залучених коштів дало можливість отримати внутрішнє джерело приросту власного капіталу банківської установи - чистий прибуток, обсягом 0,38 млрд грн і збільшити рентабельність активів на 0,1 в. п. до 0,62 \%.

Крім того, відбулося зростання ефекту фінансового левериджу на 0,13 в. п., що означає зростання рівня додаткової генерації прибутку на власний капітал. Як наслідок, рентабельність власного капіталу банківської установи зросла $33,41 \%$ до $4,13 \%$.

\section{Висновок}

Запропоновані методичні рекомендації дають можливість визначити ефект фінансового левериджу 3 урахуванням специфіки банківської діяльності. В основу розроблених рекомендацій покладено оптимізаційну модель 3 цільовою функцією максимізації приросту власного капіталу за рахунок нерозподіленого прибутку. Цільова функція враховує дотримання встановлених лімітів формування резервів на знецінення активів банківської установи й узгодження різних за термінами активів і пасивів. Крім того, обмеженнями функції максимізації приросту капіталу $\epsilon$ : неперевищення банківських витрат над доходами (забезпечення беззбитковості діяльності), 
здійснення активних операцій банківською установою у межах залишків коштів на коррахунку в НБУ, попит 3 боку позичальників i емітентів, дотримання достатнього рівня регулятивного капіталу, неперевищення розміру резервів за активними операціями відповідних лімітів. При вимірюванні ефекту фінансового левериджу рекомендовано розрахунок середньозваженої вартості залученого і позикового капіталів як співвідношення $D F L_{0}=(1-0,18) \cdot\left(\frac{119465,98}{23105607}-\frac{98150+87110}{24516440+13251179}\right) \cdot 6,89=$ $=0,0015$ або $0,15 \%$. суми процентних витрат i витрат на обслуговування кредитів та підпроцентних депозитів і залучених кредитів, що відбиває специфіку банківської діяльності.

Використання розроблених пропозицій на прикладі банківської установи дозволило сформувати цільову структуру капіталу, збільшивши рівень іiі капіталізації, i забезпечити дотримання пруденційних вимог щодо капіталу відповідно до стандартів Базель III.

Результати оптимізації структури банківського капіталу

Таблиця 7 за даними на початок року

\begin{tabular}{|c|c|c|c|c|}
\hline \multirow[b]{2}{*}{ Показник } & \multirow[b]{2}{*}{$\begin{array}{l}\text { Одиниці } \\
\text { виміру }\end{array}$} & \multicolumn{3}{|c|}{ Структура капіталу } \\
\hline & & $\begin{array}{c}\text { фактична } \\
\text { (відповідно } \\
\text { Базель III ) }\end{array}$ & $\begin{array}{c}\text { за моделлю } \\
\text { оптимізації } 3 \\
\text { функцією (2) }\end{array}$ & $\begin{array}{c}\text { цільова } \\
\text { структура } \\
\text { (прогно3) }\end{array}$ \\
\hline 1. Регулятивний капітал банку & $\begin{array}{c}\text { млрд } \\
\text { грн }\end{array}$ & 2,62 & 2,71 & 2,99 \\
\hline $\begin{array}{l}\text { 2. Мінімальний } \\
\text { капіталу }\end{array}$ & $\%$ & 14,11 & 14,0 & 13,92 \\
\hline \multirow[b]{2}{*}{ 3. Резервний буфер капіталу } & $\%$ & 2,5 & 2,5 & 2,5 \\
\hline & $\begin{array}{c}\text { млрд } \\
\text { грн }\end{array}$ & 0,54 & 0,53 & 0,65 \\
\hline 4. Мінімальний капітал першого рівня & $\%$ & 8,2 & 8,12 & 7,97 \\
\hline 5. Коефіцієнт левериджу & $\%$ & 7,67 & 7,64 & 7,58 \\
\hline $\begin{array}{l}\text { 6. Ризик капіталу системно важливих } \\
\text { банків }\end{array}$ & $\begin{array}{l}\text { частки } \\
\text { од. }\end{array}$ & 0,21 & 0,21 & 0,18 \\
\hline \multirow[b]{2}{*}{ 7. Буфер системної важливості } & $\%$ & 1,52 & 1,52 & 1,52 \\
\hline & $\begin{array}{c}\text { млрд } \\
\text { грн }\end{array}$ & 0,32 & 0,34 & 0,40 \\
\hline $\begin{array}{l}\text { 8. Мінімальний рівень сукупного } \\
\text { капіталу }\end{array}$ & $\%$ & 8,12 & 8,23 & 8,96 \\
\hline 9. Коефіцієнт покриття ліквідності & $\%$ & 96,89 & 97,81 & 103,6 \\
\hline $\begin{array}{l}\text { 10. Коефіцієнт чистого стабільного } \\
\text { фінансування }\end{array}$ & $\%$ & 126,58 & 128,43 & 132,51 \\
\hline 11. Запас міцності капітальної бази & $\begin{array}{c}\text { млрд } \\
\text { грн }\end{array}$ & 4,11 & 4,17 & 4,53 \\
\hline 12. Приріст власного капіталу & $\begin{array}{c}\text { млрд } \\
\text { грн }\end{array}$ & - & 0,14 & 0,38 \\
\hline 13. Рентабельність активів & $\%$ & 0,52 & 0,54 & 0,62 \\
\hline 14. Ефект фінансового левериджу & $\%$ & 0,15 & 0,21 & 0,28 \\
\hline 15. Рентабельність власного капіталу & $\%$ & 3,41 & 3,5 & 4,13 \\
\hline
\end{tabular}




\section{Список літератури}

1. Gropp R., Heider F. The determinants of bank capital structure. European Central Bank: Working paper series, 2009. $52 \mathrm{P}$.

2. Dr Ikpefan O. A. The impact of Bank capitalization in the Performance of Nigerian banking Industry (1986-2006) The Journal of Commerce. 2012, vol. 4, no. 1, pp 24-39.

3. Octavia M., Brown R. Determinants of bank capital structure in developing countries: regulatory capital requirement versus the standard determinants of capital structure. Department of Finance The University of Melbourne, 2008. 35 P.

4. Hancock D., Lehnert A., Passmore W, Sherlund S. The Competitive Effects of RiskBased Bank Capital Regulation: An Example from U.S. Mortgage Markets. Federal Reserve Board, 2006. $50 \mathrm{P}$.

5. Алексеєнко М. Д. Капітал банку : питання теорії і практики: монографія Київ: KHEУ, 2002. $276 \mathrm{c}$.

6. Версаль Н. І. Особливості формування депозитних ресурсів банками України Фінанси Украӥни. 2009. № 12. Київ. С. 89-95.

7. Вожжов А. П. Природа и механизм трансформации банковских ресурсов: дисс. на соиск. научн. степени докт. экон. наук: 08.00.08/УАБС .Сумы, 2007. 446 с.

8. Довгань Ж. М. Капіталізація банківської системи України. Вісник НБУ. 2008. №11. Київ. С. 10-14.

9. Реверчук С. К. Банковский капитал в системе воспроизводства. Экономическая теория и история экономической мысли. Киев 2011. № 1. С. 14-18.

10. Berg T, Gider J What explains the difference between bank and non-bank leverage? Journal of Financial and Quantitative Analysis. 2017, vol. 52, no. 6, pp. 2677-2702.

https://doi.org/10.1017/S0022109017000734

11. Катранжи Л. Л. Моделювання стратегії підвищення рівня капіталізації банку. Економіка, фінанси, право. Київ. 2016. № 11(2). C. 4 - 8.

References
1. Gropp R., Heider F. (2009) The determinants of bank capital structure. European Central Bank: Working paper series. $52 \mathrm{P}$.

2. Dr Ikpefan O. A. (2012) The impact of Bank capitalization in the Performance of Nigerian banking Industry (1986-2006) The Journal of Commerce. Vol. 4, no. 1, pp 24-39.

3. Octavia M., Brown R. (2008) Determinants of bank capital structure in developing countries: regulatory capital requirement versus the standard determinants of capital structure. Department of Finance The University of Melbourne. $35 \mathrm{P}$.

4. Hancock D., Lehnert A., Passmore W, Sherlund S. (2006) The Competitive Effects of Risk-Based Bank Capital Regulation: An Example from U.S. Mortgage Markets. Federal Reserve Board. $50 \mathrm{P}$.

5. Alekseyenko M. D. (2002). Kapital banku : pytannja teoriji i praktyky: monohrafija. Kyjiv: KNEU. 276 P.

6. Versal' N. I. (2009). Osoblyvosti formuvannja depozytnyx resursiv bankamy Ukrajiny. Finansy Ukrajiny. Vol. 12, pp 89-95.

7. Vožžov A. P. (2007). Priroda i mexanizm transformacii bankovskix resursov: diss. na soysk. naučn. stepeni dokt. ekon. nauk: 08.00.08. Sumy: UABS. 446 P.

8. Dovhan' Ž. M. (2008). Kapitalizacija bankivs'koji systemy Ukrajiny. Visnyk $N B U$. Vol.11, pp 10-14.

9. Reverčuk S. K.. (2011). Bankovskij kapital v sisteme vosproizvodstva. Ekonomičeskaja teorija $i$ ystorija ekonomičeskoj mysli. Vol. 1, pp 14-18.

10. Berg T, Gider J. (2017) What explains the difference between bank and nonbank leverage? Journal of Financial and Quantitative Analysis. Vol. 52, no. 6, pp. 26772702.

https://doi.org/10.1017/S0022109017000734

11. Katranzhy L. L. (2016)

Modeljuvannja stratehiji pidvyščennja rivnja kapitalizaciji banku. Ekonomika, finansy, pravo. Vol.11, pp 4-8.

Катранжи Леонід Леонідович - кандидат економічних наук, доцент, ДВНЗ Донецький національний технічний університет, кафедра управління і фінансово-економічної безпеки, м. Покровськ. ORCID ID: 0000-0002-1723-3498

e-mail: leonid.katranzhy@donntu.edu.ua безпеки,

Ляшок Олександр Ярославович - аспірант кафедри управління і фінансово-економічної

ДВНЗ Донецький національний технічний університет, кафедра управління і фінансовоекономічної безпеки, м. Покровськ. 
ORCID ID: 0000-0001-8192-400X

e-mail: oleksandr.liashok@gmail.com

\section{DEVELOPMENT OF THE THEORY OF FINANCIAL LEVERAGE AND MEASUREMENT OF ITS BANK EFFECTS N FINANCING INNOVATIVE COMPETITIVENESS OF ENTERPRISES}

The size and structure of capital of banking institutions determine their successful development at the micro level, and at the macro level constitute an objective basis for the efficiency of the banking system in general. The size of the bank, its specialization, other exogenous and endogenous factors impose their choice on the choice of sources of financing of active operations and the policy of formation of bank capital. The relevance of the study is increasing given the important role of the banking sector in the development of the financial system and the national economy as a whole.

In the current conditions of functioning of the monetary market, the problem of forming such capital structure of banking institutions that would ensure their sufficient capitalization is urgent. As an institution of a special type, the bank, acting as a financial intermediary under contracts, is characterized by the peculiarities of choosing the sources of capital formation, which causes the formation of a certain structure. The latter, in turn, can serve as an impulse either to increase the value of the bank, or to its depreciation and bankruptcy.

The article uses the methods of economic and mathematical modeling to formalize the effect of financial leverage of a banking institution, to determine the sufficient capitalization of banks and to justify changes in taxation of bank profits - optimization methods in financing innovative competitiveness of enterprises.

The proposed methodological recommendations make it possible to determine the effect of financial leverage, taking into account the specificity of banking activities. The developed recommendations are based on an optimization model with the objective function of maximizing equity growth at the expense of retained earnings. The objective function takes into account the observance of the established limits of formation of reserves for impairment of assets of a banking institution and the reconciliation of different in terms of assets and liabilities. In addition, restrictions on the function of maximizing capital gains are: non-excess of bank expenses over income (ensuring break-even activities), the implementation of active operations by a banking institution within the balance of funds in the account at the NBU, demand from borrowers and issuers, compliance with a sufficient level of regulatory regulation, reserves for active operations of the respective limits. When measuring the effect of financial leverage, it is recommended to calculate the weighted average cost of borrowed and borrowed capital as a ratio of the amount of interest expenses and costs of servicing loans and interest-bearing deposits and borrowings, reflecting the specifics of banking activities.

The use of the developed proposals on the example of a banking institution allowed to form the target capital structure, increasing its capitalization level through efficient use of attracted funds, which allowed to obtain an internal source of growth of the bank's own capital, and to ensure compliance with prudential capital requirements in accordance with Basel III standards.

Keywords: bank, capital, capital structure, financial leverage, bank profit

Katranzhy Leonid - Candidate of Sciences (Economics), associate professor, Donetsk National Technical University, Department of Management, Finance and Economic Security, Pokrovsk

ORCID ID: 0000-0002-1723-3498

e-mail: leonid.katranzhy@donntu.edu.ua

Liashok Oleksandr - PhD Student, Donetsk National Technical University, Department of Management, Finance and Economic Security, Pokrovsk

ORCID ID: 0000-0001-8192-400X

e-mail: oleksandr.liashok@gmail.com

\section{РАЗВИТИЕ ТЕОРИИ ФИНАНСОВОГО ЛЕВЕРИДЖА И ИЗМЕРЕНИЕ ЕГО БАНКОВСКИХ ЭФФЕКТОВ ПРИ ФИНАНСИРОВАНИИ ИННОВАЦИОННОЙ КОНКУРЕНТОСПОСОБНОСТИ ПРЕДПРИЯТИЙ}

В статье адаптирован традиционный подход к измерению эффекта финансового левериджа в реальном секторе экономики к специфике банковской деятельности путем определения методических подходов к расчету средневзвешенной стоимости привлеченного и ссудного капиталов, которые дополнительно к коэффициенту структуры капитала, включают налоговый корректор и дифференциал 
финансового левериджа. Кроме того, рекомендации содержат модель максимизации формирования собственного капитала банка при соблюдении установленных лимитов формирования резервов на обесценивание активов банковского учреждения и согласования разных по срокам активов и пассивов, обеспечении прибыльности осуществляемых банком операций и выполнения нормативов капитала. Измерение эффектов финансового левериджа с применением данного подхода, как ожидается, позволит на практике обосновывать решение относительно финансового обеспечения инновационной конкурентоспособности предприятий, оценивать их экономическую целесообразность в условиях ограниченного доступа к рынкам капитала.

Использование разработанных предложений и рекомендаций относительно совершенствования формирования банковского капитала будет способствовать повышению его эффективности, снижению уровня рисков, будет обеспечивать достаточность банковского капитала и иметь позитивное влияние на рост стоимости банковского бизнеса и капитализацию банковской системы, ее стабильность и экономический рост национальной экономики.

Ключевые слова: банк, капитал, структура капитала, финансовый леверидж, банковская прибыль

Катранжи Леонид Леонидович - к.э.н., доцент, ГВУЗ «Донецкий национальный технический университет», кафедра управления и финансово-экономической безопасности, Покровск

ORCID ID: 0000-0002-1723-3498

e-mail: leonid.katranzhy@donntu.edu.ua

Ляшок Александр Ярославович - аспирант кафедры управления и финансово-экономической безопасности, ГВУЗ «Донецкий национальный технический университет», Покровск

ORCID ID: 0000-0001-8192-400X

e-mail: oleksandr.liashok@gmail.com 